\title{
Faktor-faktor Yang Mempengaruhi Kinerja Keuangan Perusahaan Properti dan Real Estate di BEI
}

\author{
Eva Sriwiyanti ${ }^{1)}$, Elfina Okto Posmaida Damanik ${ }^{2)}$, Sri Martina ${ }^{3)}$ \\ ${ }^{1,2,3}$ Prodi Akuntansi, Fakultas Ekonomi, Universitas Simalungan \\ 1evasriwiyanti.s@gmail.com, ${ }^{2}$ elfinaopdse83@gmail.com, ${ }^{3}$ srimartina999@gmail.com
}

\begin{abstract}
This study aims to determine the factors that affect the financial performance of property and real estate companies listed on the Indonesia Stock Exchange in 2016-2020. Several previous studies on different financial performance. Therefore, other research needs to be conducted to re-test the theory of financial performance. The study population was 52 property and real estate companies. The sampling method used was purposive sampling method, so that 29 sample companies were obtained for 5 years of observation (2016-2020) with 145 observations (observations). The research data is obtained from sample companies which can be downloaded from the Indonesia Stock Exchange website. The data analysis technique used is multiple regression analysis. The data analysis process that is carried out first is the classical assumption test, multiple regression analysis and then testing the hypothesis.Simultaneously, capital structure, firm size, total assets turnover have a significant effect on financial performance. Partially shows that the capital structure has a negative and significant effect on financial performance. Firm size has no effect on financial performance while total asset turnover has a positive and significant effect on financial performance.
\end{abstract}

Keywords: Capital Structure, Financial Performance, Firm Size, Total Asset Turnover

\begin{abstract}
ABSTRAK
Penelitian ini bertujuan untuk mengetahui faktor-faktor yang mempengaruhi kinerja keuangan perusahaan property dan real estate yang terdaftar di Bursa Efek Indonesia tahun 2016-2020. Beberapa penelitian sebelumnya mengenai kinerja keuangan yang berbeda. Oleh karena itu, perlu dilakukan penelitian lain untuk menguji kembali teori kinerja keuangan. Populasi penelitian adalah 52 perusahaan property dan real estate. Metode pengambilan sampel yang digunakan adalah metode purposive sampling, sehingga diperoleh 29 perusahaan sampel selama 5 tahun pengamatan (2016-2020) dengan 145 pengamatan. Data penelitian diperoleh dari sampel perusahaan yang dapat diunduh dari website Bursa Efek Indonesia. Teknik analisis data yang digunakan adalah analisis regresi berganda. Proses analisis data yang dilakukan pertama adalah uji asumsi klasik, analisis regresi berganda kemudian uji hipotesis. Secara simultan struktur modal, ukuran perusahaan, total assets turnover berpengaruh signifikan terhadap kinerja keuangan. Secara parsial menunjukkan bahwa struktur modal berpengaruh negatif dan signifikan terhadap kinerja keuangan. Ukuran perusahaan tidak berpengaruh terhadap kinerja keuangan sedangkan total asset turnover berpengaruh positif dan signifikan terhadap kinerja keuangan.
\end{abstract}

Kata Kunci: Kinerja Keuangan, Perputaran Total Aset, Struktur Modal, Ukuran Perusahaan

ISSN: 2355-0295, e-ISSN: 2549-8932 


\section{PENDAHULUAN}

Kinerja keuangan adalah suatu informasi keuangan perusahaan dalam periode waktu tertentu sebagai capaian dari keberhasilan perusahaan dalam mengatur keuangan. Informasi mengenai kinerja keuangan dapat membantu investor dalam melakukan putusan yang baik. ROA dijadikan sebagai indikator yang dipergunakan untuk menilai kinerja perusahaan. ROA dipergunakan untuk mengukur efektivitas perusahaan dalam menentukan keuntungan. ROA yang nilainya membesar menunjukkan bahwa kinerja perusahaan lebih baik.

Ada beberapa faktor yang mempengaruhi kinerja keuangan yaitu struktur modal, ukuran perusahaan dan total aset turnover. Faktor pertama yang diduga mempengaruhi kinerja keuangan yaitu struktur modal. Menurut Kusumajaya (2011), struktur modal merupakan perbandingan antara jumlah hutang jangka panjang dengan modal sendiri perusahaan. Dalam pendanaan kegiatan perusahaan, perusahaan harus dapat mengkombinasikan hal yang dapat memberikan laba dari modal hutang. Keadaan ini mencerminkan modal yang diatur dengan tepat sesuai dengan hutang jangka panjang dan modal saham. Struktur modal diproksikan Debt to Equity dapat mendongkrak laba perusahaan dan para pemegang saham pun ikut memperoleh laba.

Penelitian Hartoyo (2018), Zakiyah, Salim dan Wahono (2018) dan Rahayu (2019) memberikan bukti struktur modal berpengaruh signifikan terhadap kinerja perusahaan. Namun berbanding terbalik penelitian oleh Tambunan, Jessica Talenta Agustina dan Prabawani (2018) yang menunjukkan struktur modal berpengaruh tidak signifikan terhadap kinerja keuangan.

Faktor kedua yang diduga dapat mempengaruhi kinerja keuangan yaitu ukuran perusahaan. Ukuran perusahaan tercermin dari nilai total aktiva perusahaan pada neraca akhir tahun. Tahapan kedewasaan (maturity) perusahan digambarkan dari total asset yang besar.
Ukuran perusahaan meningkat menjadi idola kepercayaan investor dalam hal informasi keuangan yang lebih lengkap dan dapat meningkatnya kinerja perusahaan secara terus-menerus.

Penelitian Wibowo (2019) dan Rahayu (2019) membuktikan bahwa ukuran perusahaan berpengaruh secara signifikan terhadap kinerja perusahaan. Namun berbanding terbalik dengan penelitian Hartoyo (2018), Fajaryani and Suryani (2018), Tambunan, Jessica Talenta Agustina dan Prabawani (2018) dan Lestari (2020) yang membuktikan ukuran perusahaan tidak memperngaruhi kinerja perusahaan.

Faktor terakhir yang diduga dapat memengaruhi kinerja keuangan yaitu total aset turnover. Rasio ini menjelaskan tingkat ketepatan cara total aktiva perusahaan dalam menjalankan proses penjualan atau memberi petunjuk putaran aset dalam kurun waktu tertentu. Apabila rasio ini mengalami peningkatan menggambarkan bahwa perusahaan mempunyai efisien yang kian bertambah dengan aset supaya penjualan bertambah banyak dan laba juga meningkat.

Penelitian Yunita, Susyanti dan Wahono (2020) membuktikan bahwa total asset turnover berpengaruh secara signifikan terhadap kinerja perusahaan. Namun berbanding terbalik dengan hasil penelitian Lestari (2020) yang menyatakan total asset turnover tidak mempengaruhi kinerja perusahaan.

Melihat penelitian sebelumnya, penulis mengangkat judul "Faktor- faktor yang mempengaruhi kinerja keuangan pada perusahaan property dan real estate yang terdaftar di Bursa Efek Indonesia Tahun 2016 - 2020".

\section{KAJIAN LITERATUR}

Kinerja Keuangan (Y)

Menurut (Trianto, 2018) kinerja keuangan dapat dijelaskan dengan melihat laporan keuangan perusahaan melalui rasio keuangannya. Keberhasilan keuangan perusahaan yang telah terjadi selalu dievaluasi sehingga kinerja keuangan sangat dibutuhkan. Dan menurut Wibowo (2019), 
Kinerja keuangan adalah penilaian keuangan perusahaan melalui teknik analisis keuangan untuk menemukan keadaan keuangan baik atau buruk pada perusahaan yang menentukan capaian kerja dalam waktu tertentu.

\section{Struktur Modal $\left(\mathbf{X}_{1}\right)$}

Menurut Irham (2014) struktur modal adalah suatu rancangan modal asing yang termasuk bagian finansial perusahaan dari hutang dan modal sendiri dalam hal pembiayaan suatu entitas. dan menurut Sartono (2016), "struktur modal adalah perbandingan jumlah hutang jangka pendek yang bersifat permanen, hutang jangka panjang, saham preferen dan saham biasa. Serta menurut (Mahmood et al., 2017) bahwa gabungan kewajiban dari kewajiban jangka panjang dan jangka pendek disebut sebagai struktur modal.

\section{Ukuran Perusahaan $\left(\mathbf{X}_{2}\right)$}

Suharli (2006) mengatakan ukuran perusahaan dapat dilihat dari total aset yang dimiliki oleh perusahaan. Menurut Warsono (2012), Ukuran perusahaan yaitu suatu penilaian perusahaan ditunjukkan oleh total asset. Sedangkan Dewi ( 2013) mengatakan "Ukuran perusahaan adalah peningkatan adanya kenyataan bahwa perusahaan besar akan memiliki proses tindakan pasar yang besar, nilai buku yang besar, dan tingginya laba".

\section{Total aset turnover $\left(\mathrm{X}_{3}\right)$}

Menurut Srimindarti (2009), Total assets turnover sebagai proporsi total aset dengan penjualan yang diperoleh selama periode tertentu. Toto (2011) juga mengatakan Rasio Total Asset Turnover menilai perputaran aktiva secara menyeluruh karena cakupannya paling luas. Tanpa melihat jenis usaha, rasio ini dapat menggambarkan kemampuan seluruh aktiva untuk memperoleh penjualan. Sedangkan Yunita, Susyanti and Wahono (2020) menyatakan bahwa total assets turnover merupakan rasio yang berfungsi menilai perusahaan untuk mampu berkembang dengan menggunakan asetnya untuk mencapai hasil penjualan yang diinginkan.

\section{Pengembangan Hipotesis}

Pengaruh struktur modal terhadap kinerja keuangan

Menurut Irham (2014) struktur modal adalah suatu rancangan modal asing yang termasuk bagian finansial perusahaan dari hutang dan modal sendiri dalam hal pembiayaan suatu entitas. Operasi perusahaan dibiayai oleh pembiayaan, sehingga penting untuk mempertimbangkan metode perusahaan dalam membuat kombinasi yang menghasilkan antara penggunaan ekuitas dan dana hutang. Ini menggambarkan struktur modal yang benar antara hutang jangka panjang dan saham. Struktur Modal meningkatkan keuntungan perusahaan, yang pada waktunya meningkatkan kekayaan pemilik, dan meningkatkan ikatan baik dengan kreditur dengan meningkatkan kekayaan perusahaan.

Penelitian ini searah dengan penelitian Hartoyo (2018), Zakiyah, Salim and Wahono (2018) dan Rahayu (2019) yang mengemukakan bahwa struktur modal mempengaruhi secara signifikan terhadap kinerja perusahaan. Namun berbanding terbalik dengan Tambunan, Jessica Talenta Agustina dan Prabawani (2018) yang menunjukkan struktur modal tidak mempengaruhi secara signifikan terhadap kinerja keuangan.

$\mathrm{H}_{1}$ : Struktur modal berpengaruh positif dan signifikan terhadap kinerja keuangan

\section{Pengaruh ukuran perusahaan terhadap kinerja keuangan}

Ukuran perusahaan termasuk penilaian proses operasional perusahaan yang digambarkan dari nilai total aktiva perusahaan pada laporan keuangan. Dari segi total aset, perusahaan dengan total aset yang tinggi memberi informasi bahwa perusahaan tersebut telah meraih tingkat kematangan. Perubahan tingkat kinerja keuangan suatu perusahaan dipengaruhi oleh skalanya. Ukuran perusahaan dapat menentukan Kinerja perusahaan baik atau 
buruk. Investor lebih mempercayai perusahaan besar karena peningkatan kinerja perusahaan dilakukan secara terus menerus untuk menghasilkan laba yang berkualitas.

Penelitian ini searah dengan Wibowo (2019) dan Rahayu (2019) yang mengemukakan bahwa ukuran perusahaan mempengaruhi kinerja perusahaan secara signifikan. Namun berbeda dengan penelitian Hartoyo (2018), Fajaryani and Suryani (2018), Tambunan, Jessica Talenta Agustina dan Prabawani (2018) dan Lestari (2020) yang menunjukkan ukuran perusahaan tidak berpengaruh terhadap kinerja perusahaan.

$\mathrm{H}_{2}$ : Ukuran perusahaan berpengaruh positif dan signifikan terhadap kinerja keuangan

\section{Pengaruh total asset turnover terhadap kinerja keuangan}

Tingkat perputaran aset total menunjukkan efisiensi semua aset perusahaan untuk penjualan. rasio ini mengukur berapa banyak aset yang digunakan dalam suatu aktivitas, atau seberapa sering aset berubah dalam periode waktu tertentu. Jika rasio cenderung naik, situasi ini merupakan kondisi perusahaan menggunakan aset lebih efektif untuk meningkatkan penjualan, yang akan mempengaruhi keuntungan perusahaan.

Penelitian ini searah dengan penelitian Yunita, Susyanti and Wahono (2020) yang menunjukkan Total Asset Turnover berpengaruh secara signifikan terhadap kinerja perusahaan. Namun berbeda dengan penelitian Srimindarti (2009) dan Lestari (2020) yang menunjukkan Total Asset Turnover tidak berpengaruh terhadap kinerja perusahaan.

$\mathrm{H}_{3}$ : Total aset turnover berpengaruh positif dan signifikan terhadap kinerja keuangan

\section{Pengaruh struktur modal, ukuran perusahaan dan total asset turnover terhadap kinerja keuangan \\ Struktur Modal meningkatkan keuntungan perusahaan, yang pada}

waktunya meningkatkan kekayaan pemilik, dan memperbaiki ikatan baik dengan kreditur dengan meningkatkan kekayaan perusahaan.

Investor lebih mempercayai perusahaan besar karena peningkatan kinerja perusahaan dilakukan secara terus menerus untuk menghasilkan laba yang berkualitas.

Total asset turnover menunjukkan efisiensi semua aset perusahaan untuk penjualan. rasio ini mengukur berapa banyak aset yang digunakan dalam suatu aktivitas, atau seberapa sering aset berubah dalam periode waktu tertentu. Jika rasio cenderung naik, situasi ini merupakan kondisi perusahaan menggunakan aset lebih efektif untuk meningkatkan penjualan, yang akan mempengaruhi keuntungan perusahaan

$\mathrm{H}_{4}$ : Struktur modal, ukuran perusahaan dan total aset turnover berpengaruh signifikan terhadap kinerja keuangan

\section{METODE PENELITIAN}

Desain Penelitian

Desain penelitian ini adalah penelitian kausal bermanfaat untuk menngungkapkan hubungan antar suatu peristiwa atau variabel. Desain kausal atau hubungan sebab akibat yang menjadi pilihan peneliti.

Populasi dan Sampel Penelitian

Penelitian ini mengambil jumlah populasi sebanyak 52 perusahaan property dan real estate. Sesuai kriteria diatas yang dijadikan sampel penelitian adalah sebanyak 29 perusahaan. Periode penelitian sebanyak 5 tahun dari tahun 2016-2020 maka pengamatan sampel penelitian ini sebanyak 145 data pengamatan. Teknik pengumpulan sampel menggunakan metode purposive sampling, yaitu teknik penentuan sampel berdasarkan suatu kriteria tertentu.

Kriteria yang digunakan dalam penentuan sampel pada penelitian ini, yaitu:

1. Perusahaan sektor property dan real estate yang terdaftar di BEI sesuai dengan tahun pengamatan 2016-2020. 
2. Perusahaan menerbitkan laporan tahunan yang telah diaudit sesuai periode tahun pengamatan 2016-2020.

3. Perusahaan property dan real estate yang memiliki laba selama periode tahun pengamatan 2016-2020

4. Memiliki data yang lengkap mengenai struktur modal, ukuran perusahaan, total aset turnover dan kinerja perusahaan sesuai variabel yang digunakan dalam penelitian.

\section{Defenisi Operasional dan Pengukuran Variabel}

Struktur modal merupakan seberapa besar hutang perusahaan dibiayai oleh modal perusahaan. Penelitian ini menilai struktur modal dengan menggunakan Debt to Equity Rasio melalui rumus sebagai berikut: DER $=\frac{\text { Total Hutang }}{\text { Total Ekuitas }}$

Ukuran perusahaan termasuk penilaian proses operasional perusahaan yang digambarkan dari nilai total aktiva perusahaan pada laporan keuangan. Adapaun rumus ukuran perusahaan adalah sebagai berkut:

Ukuran perusahaan $=$ Logaritma Natural (Total asset)

Total assets turnover mengukur berapa banyak aset yang digunakan dalam suatu aktivitas, atau seberapa sering aset berubah dalam periode waktu tertentu. Dalam Penelitian ini Total assets turnover dinilai dengan rumus sebagai berikut :

Total assets turnover $=$ Penjualan

$$
\text { Total aset }
$$

Teknik dan instrumen Pengumpulan Data

Instrumen pengumpulan data yang digunakan dalam penelitian ini adalah observasi non partisipatif yakni membaca, mengumpulkan, dan menulis data, informasi, dan informasi yang peneliti tidak berpartisipasi secara langsung, dan hanya sebagai pengamat independen Sugiyono (2013). Data adalah data laporan keuangan tahunan perusahaan property dan real estate yang telah terdaftar pada Bursa Efek Indonesia dan sesuai dengan kriteria pemilihan sampel. Perangkat lunak statistic yaitu SPSS, digunakan untuk pemrosesan data.

\section{Teknik Analisis Data}

Teknik analisis data yang digunakan adalah analisis regresi linier berganda, uji hipotesis dengan uji t (uji parsial) dan uji $\mathrm{F}$ (uji simultan), serta analisis koefisien determinasi.

\section{PEMBAHASAN}

Deskriptif Analisis

Analisis statistik deskriptif digunakan untuk memahami deskripsi suatu data yang terlihat dari nilai minimum, maksimum, dan nilai rata-rata (mean), dan nilai standar deviasi dari Struktur Modal (X1), Ukuran Perusahaan (X2), Total aset turnover (X3), dan Kinerja Perusahaan (Y).

Tabel 1. Descriptive Statistics

\begin{tabular}{|c|c|c|c|c|c|}
\hline & $\mathbf{N}$ & Minimum & Maximum & Mean & $\begin{array}{l}\text { Std. } \\
\text { Deviation }\end{array}$ \\
\hline $\begin{array}{l}\text { Kinerja } \\
\text { Keuangan } \\
\text { (Y) }\end{array}$ & 145 & $-37,52$ & 64,76 & 471,23 & 841,887 \\
\hline $\begin{array}{l}\text { Struktur } \\
\text { Modal (X1) }\end{array}$ & 145 & 4,33 & 309,07 & $7.403,41$ & $6.233,832$ \\
\hline $\begin{array}{l}\text { Ukuran } \\
\text { Perusahaan } \\
\text { (X2) }\end{array}$ & 145 & 25,68 & 31,74 & $2.949,66$ & 133,144 \\
\hline TATO (X3) & 145 & 0 & 94 & 17,09 & 11,078 \\
\hline $\begin{array}{l}\text { Valid N } \\
\text { (listwise) }\end{array}$ & 145 & & & & \\
\hline
\end{tabular}

1. Nilai minimum dari kinerja perusahaan adalah $-37,52$ dan nilai maksimum dari nilai perusahaan adalah 64,76 . Sementara mean dan standar deviasi dari kinerja perusahaan adalah 471,23 dan 841,887 .

2. Nilai minimum dari struktur modal adalah 4,33 dan nilai maksimum dari struktur modal 309,07. Sementara mean dan standar deviasi 
dari Struktur modal adalah 7.703,41 dan $6.233,832$.

3. Nilai minimum dari Ukuran Perusahaan adalah 25,68 dan nilai maksimum dari ukuran perusahaan 31,74. Sementara rata-rata dan standar deviasi dari ukuran perusahaan adalah 2.949,66 dan 133,144 .

4. Nilai minimum dari tato adalah 0 dan nilai maksimum dari tato adalah 94. Sementara rata-rata dan standar deviasi dari tato adalah 17,09 dan 11,078

Analisis Regresi Linier Berganda

Analisis regresi linier berganda digunakan untuk mengetahui besarnya pengaruh variabel - variabel bebas (independen) yaitu struktur modal, ukuran perusahan dan total aset turnover dalam memprediksi variabel terikat (dependen) yaitu kinerja keuangan, juga untuk melihat arah hubungan positif atau negatif terhadap variabel independen dengan variabel dependen.

Tabel 2 Hasil Analisis Regresi Linier Berganda

\begin{tabular}{|c|c|c|c|c|c|}
\hline \multirow[t]{2}{*}{ Model } & \multicolumn{2}{|c|}{$\begin{array}{c}\text { Unstandardi } \\
\text { zed } \\
\text { Coefficients }\end{array}$} & $\begin{array}{c}\text { Standardi } \\
\text { zed } \\
\text { Coefficien } \\
\text { ts }\end{array}$ & $\mathbf{t}$ & $\begin{array}{l}\text { Sig } \\
\text {. }\end{array}$ \\
\hline & B & $\begin{array}{c}\text { Std. } \\
\text { Erro } \\
r\end{array}$ & Beta & & \\
\hline $\begin{array}{l}\text { (Consta } \\
\text { nt) }\end{array}$ & $\begin{array}{l}- \\
6.957\end{array}$ & $\begin{array}{l}6.51 \\
9\end{array}$ & & $\begin{array}{l}- \\
1.06 \\
7\end{array}$ & $\begin{array}{l}.28 \\
8\end{array}$ \\
\hline X1 & -.030 & .005 & -.391 & $\begin{array}{l}- \\
6.53 \\
5\end{array}$ & $\begin{array}{l}.00 \\
0\end{array}$ \\
\hline X2 & .270 & .224 & .073 & $\begin{array}{l}1.20 \\
8\end{array}$ & $\begin{array}{l}.22 \\
9\end{array}$ \\
\hline $\mathbf{X 3}$ & $\begin{array}{l}34.77 \\
7\end{array}$ & $\begin{array}{l}3.10 \\
4\end{array}$ & .657 & $\begin{array}{l}11.2 \\
05\end{array}$ & $\begin{array}{l}.00 \\
0\end{array}$ \\
\hline
\end{tabular}

Sumber : Data Diolah SPSS, 2021
Hasil analisis regresi linear berganda yang didapatkan dengan menggunakan spss adalah sebagai berikut :

1. $\mathrm{X}_{1}$ (struktur modal) memiliki nilai koefisien regresi sebesar $-0,030$ dan berpengaruh negatif terhadap kinerja keuangan

2. $\mathrm{X}_{2}$ (ukuran perusahaan) memiliki nilai koefisien regresi sebesar 0,270 dan tidak berpengaruh terhadap kinerja keuangan.

3. $\mathrm{X}_{3}$ (total aset turnover) memiliki nilai koefisien regresi sebesar 34,777 dan berpengaruh positif terhadap kinerja keuangan.

Uji Hipotesis

a. Uji Simultan (Uji F)

Uji F dilakukan bertujuan untuk melihat adanya pengaruh secara bersama-sama variabel independen terhadap variabel dependen. Tingkat signifikansi yang digunakan adalah sebesar 5\%.

Tabel 3 Hasil Uji Simultan ANOVA $^{\mathrm{a}}$

\begin{tabular}{llllll}
\hline Model & $\begin{array}{l}\text { Sum of } \\
\text { Squares }\end{array}$ & df & $\begin{array}{l}\text { Mean } \\
\text { Squar } \\
\text { e }\end{array}$ & F & Sig. \\
\hline $1 \quad \begin{array}{l}\text { Regressi } \\
\text { on }\end{array}$ & $\begin{array}{l}1.731 .0 \\
82\end{array}$ & 3 & 577.0 & 53.4 & .00 \\
& & & 27 & 73 & $0^{\mathrm{b}}$ \\
\hline Residual & 1.467 .5 & 13 & 10.79 & & \\
& 67 & 6 & 1 & & \\
\hline Total & 3.198 .6 & 13 & & & \\
& 48 & 9 & & & \\
& & & & & \\
\end{tabular}

a. Dependent Variable: $Y$

b. Predictors: (Constant), X3, X1, X2

Berdasarkan tabel 3, nilai signifikansi $\mathrm{F}$ hitung sebesar $0,000<0,05$ maka artinya struktur modal, ukuran perusahaan dan total aset turnover berpengaruh secara signifikan terhadap kinerja keuangan.

Uji t (Uji Parsial)

Uji t dilakukan bertujuan untuk melihat adanya pengaruh secara parsial variabel 
independen terhadap variabel dependen dengan tingkat signifikansi sebesar 5\%.

Berdasarkan hasil Uji $\mathrm{T}$ dari tabel 1 dapat disimpulkan sebagai berikut:

1. X1 (struktur modal) menghasilkan nilai signifikansi $0,000<0,05$ sehingga dibuktikan bahwa struktur modal berpengaruh signifikan terhadap kinerja keuangan.

2. X2 (ukuran perusahaan) menghasilkan nilai signifikansi $0,229>0,05$ sehingga dibuktikan bahwa ukuran perusahaan tidak berpengaruh terhadap kinerja keuangan.

3. X3 (total aset turnover) menghasilkan nilai signifikansi $0,000<0,05$ sehingga dibuktikan bahwa total aset turnover berpengaruh signifikan terhadap kinerja keuangan.

\section{Koefisien Determinasi}

Uji ini dilakukan untuk mengukur kekuatan variabel-variabel independen yaitu struktur modal, ukuran perusahan dan aset turnover dalam mengungkapkan variabel dependen yaitu kinerja keuangan.

Tabel 3 Hasil Koefisien Determinasi Model Summary ${ }^{\mathrm{b}}$

\begin{tabular}{lll}
\hline Model & R Square & Adjusted R Square \\
\hline $\mathbf{1}$ & .541 & .531
\end{tabular}

a. Predictors: (Constant), X3, X1, X2

b. Dependent Variable: Y

Sumber : Data Diolah SPSS, 2021

Berdasarkan Tabel 3, nilai koefisien determinasi terletak pada kolom Adjusted $R$ Square sebesar 0,531 yang menjelaskan seluruh variabel bebas, yakni struktur modal, ukuran perusahaan dan total aset turnover berpengaruh terhadap variabel kinerja keuangan sebesar 53,1\%, dan sisanya sebesar $46,9 \%$ dipengaruhi oleh faktorfaktor lain.

\section{PEMBAHASAN}

Pengaruh struktur modal terhadap kinerja keuangan

Dari hasil pengujian secara parsial, struktur modal berpengaruh negatif dan signifikan terhadap kinerja keuangan.

Perusahaan harus memiliki modal besar jika memiliki hutang yang besar, dan harus mampu menghasilkan laba yang lebih besar, dan sebaliknya. Dengan demikian perusahaan seharusnya berjuang mempertahankan dan meningkatkan stabilitas penjualan dan pertumbuhan perusahaan, mengatur struktur asset perusahaan, dan menaikkan laba serta meningkatkan fleksibilitas keuangan agar struktur modal perusahaan dapat optimal.

Penelitian ini sejalan dengan penelitian Fajaryani dan Suryani (2018) yang menunjukkan struktur modal berpengaruh negatif dan signifikan terhadap kinerja keuangan. Namun berbanding terbalik dengan penelitian Tambunan, Jessica Talenta Agustina dan Prabawani (2018) yang menunjukkan struktur modal berpengaruh tidak signifikan terhadap kinerja keuangan.

\section{Pengaruh ukuran perusahaan terhadap kinerja keuangan}

Dari hasil pengujian secara parsial ukuran perusahaan tidak berpengaruh terhadap kinerja keuangan.

Hasil tersebut terjadi karena perusahaan dengan ukuran yang besar belum tentu menjamin bahwa kinerja keuangan perusahaan tersebut baik karena perusahaan besar lazimnya tidak sering menambah investasi baru yang terkait dengan ekspansi perusahaan sebelum perusahaan membayar kewajibannya serta tidak dibarengi dengan peningkatan manajemen yang lebih baik dalam mengelola perusahaan. Apabila perusahaan berinisiatif menambah investasi maka dapat meningkatkan keuntungan yang maksimal.

Penelitian ini sejalan dengan penelitian yang telah dilakukan oleh Hartoyo (2018), Fajaryani and Suryani (2018), Tambunan, Jessica Talenta Agustina dan Prabawani 
(2018) dan Lestari (2020) yang menunjukkan ukuran perusahaan tidak signifikan berpengaruh terhadap kinerja perusahaan. Namun berbanding terbalik dengan penelitian yang yang telah dilakukan oleh Wibowo (2019) dan Rahayu (2019) yang menunjukkan ukuran perusahaan berpengaruh secara signifikan terhadap kinerja perusahaan.

\section{Pengaruh total aset turnover terhadap kinerja keuangan}

Dari hasil pengujian secara parsial, total aset turnover berpengaruh positif dan signifikan terhadap kinerja keuangan.

Tingkat perputaran aset total menunjukkan efisiensi semua aset perusahaan untuk penjualan. rasio ini mengukur berapa banyak aset yang digunakan dalam suatu aktivitas, atau seberapa sering aset berubah dalam periode waktu tertentu. Jika rasio cenderung naik, situasi ini merupakan kondisi perusahaan menggunakan aset lebih efektif untuk meningkatkan penjualan, yang akan mempengaruhi keuntungan perusahaan.

Penelitian ini searah dengan penelitian Yunita, Susyanti and Wahono (2020) yang membuktikan total aset turnover berpengaruh secara signifikan terhadap

\section{REFERENSI}

Dewi, A. S. M. Dan A. W. (2013). Pengaruh Struktur Modal, Profitabilitas, Dan Ukuran Perusahaan Pada Nilai Perusahaan. E- Jurnal Akuntansi Universitas Udayana. 4(2): 514-530.

https://ojs.unud.ac.id/index.php/Akunt ansi/article/view/6233

Fajaryani, N. L. G. S., \& Suryani, E. (2018). Struktur Modal, Likuiditas, Dan Ukuran Perusahaan Terhadap Kinerja Keuangan Perusahaan. Jurnal Riset Akuntansi Kontemporer, 10(2), 74-79.

DOI: http://dx.doi.org/10.23969/jrak.v $10 \mathrm{i} 2.1370$ kinerja perusahaan. Namun berbanding terbalik dengan penelitian yang telah dilakukan oleh Srimindarti (2009) dan Lestari (2020) yang menunjukkan total aset turnover tidak berpengaruh terhadap kinerja perusahaan.

\section{Pengaruh struktur modal, ukuran perusahaan dan total aset turnover terhadap kinerja keuangan}

Dari hasil pengujian secara simultan, struktur modal, ukuran perusahaan dan total aset turnover berpengaruh secara signifikan terhadap kinerja keuangan.

\section{SIMPULAN}

Berdasarkan hasil pengujian hipotesis, maka kesimpulan dari hasil penelitian bahwa Struktur modal berpengaruh negatif dan signifikan terhadap kinerja keuangan, ukuran perusahaan tidak berpengaruh terhadap kinerja keuangan, dan total aset turnover berpengaruh positif dan signifikan terhadap kinerja keuangan. Secara simultan, membuktikan bahwa struktur modal, ukuran perusahaan dan total asset turover berpengaruh signifikan terhadap kinerja keuangan.

Hartoyo, H. (2018). Hubungan Current Ratio, Struktur Modal, Dan Ukuran Perusahaan Terhadap Kinerja Keuangan Perusahaan Pertambangan Yang Terdaftar Di Bei Periode 20142016. Jurnal Maksipreneur: Manajemen, Koperasi, Dan Entrepreneurship, $\quad 8(1), \quad 81-97$. DOI: http://dx.doi.org/10.30588/jmp.v $8 \mathrm{i} 1.375$

Irham, F. (2014). Manajemen Keuangan Perusahaan Dan Pasar Modal.

Kusumajaya, D. K. O. (2011). Pengaruh Struktur Modal Dan Pertumbuhan Perusahaan Terhadap Profitabilitas Dan Nilai Perusahaan Pada Perusahaan Manufaktur Di Bursa Efek Indonesia. Universitas Udayana, 
Denpasar: Tesis Yang Tidak Dipublikasikan.

Https://Www.Academia.Edu/7689418

/Pengaruh_Struktur_Modal_Dan_Pert umbuhan_Perusahaan_Terhadap_Prof itabilitas_Dan_Nilai_Perusahaan_Pad a_Perusahaan_Manufaktur_Di_Bursa _Efek_Indonesia

Lestari, P. (2020). Pengaruh Likuiditas, Der, Firm Size, Dan Asset Turnover Terhadap Kinerja Keuangan. Jurnal Neraca: Jurnal Pendidikan Dan Ilmu Ekonomi Akuntansi, 4(1), 1-10. DOI: http://dx.doi.org/10.31851/nerac a.v4i1.3843

Mahmood, B., Iqbal, M. S., Zafar, M. J., \& Khalid, B. (2017). Textile Industry Socializing, Economic Gains And Capital Structure: A Case Study Of Faisalabad, Pakistan. J. Appl. Environ. Biol. Sci, 7(9), 1-7.

https://www.researchgate.net/profile/ Muhammad-Iqbal169/publication/319502279_Textile_I ndustry_Socializing_Economic_Gains _and_Capital_Structure_A_Case_Stud y_of_Faisalabad_Pakistan/links/59af7 6c1aca2720370736957/TextileIndustry-Socializing-EconomicGains-and-Capital-Structure-A-CaseStudy-of-Faisalabad-Pakistan.pdf

Rahayu, D. P. (2019). Pengaruh Ukuran Perusahaan, Struktur Modal, Dan Likuiditas Terhadap Kinerja Keuangan Pada Perusahaan Makanan Dan Minuman Yang Tercatat Di Bursa Efek Indonesia (Bei) Tahun 2013-2017. Jakk ( Jurnal Akuntansi Dan Keuangan Kontemporer ) Volume 2 No. 1.

DOI: http://dx.doi.org/10.30596\%2Fja kk.v2i1.5705

Sartono. (2016). Manajemen Keuangan: Teori Dan Aplikasi. In Yogyakarta: Bpfe-Yogyakarta (Ed. 4).

Srimindarti, C. (2009). Pengaruh Current Ratio, Total Assets Turnover, Dan Return On Investment Terhadap Kinerja Perusahaan Pada Industri Food And Beverages Yang Terdaftar
Di Bej. Telaah Manajemen, 6(2), 249572.

https://unisbank.ac.id/ojs/index.php/fe 5/article/view/2076

Sugiyono. (2013). Metodologi Penelitian Bisnis. In Bandung : Alfabeta.

Suharli, M. (2006). Studi Empiris Mengenai Pengaruh Profitabilitas,

Leverage, Dan Harga Saham Terhadap Jumlah Dividen Tunai (Studi Pada Perusahaan Yang Terdaftar Di Bursa Efek Jakarta Periode 2002-2003). Jurnal Manajemen, Akuntansi \& Sistem Informasi, 6(2), 243-256. https://ejournal.undip.ac.id/index.php/ maksi/article/view/258

Tambunan, Jessica Talenta Agustina Dan Prabawani, B. (2018). Pengaruh Ukuran Perusahaan, Leverage Dan Struktur Modal Terhadap Kinerja Keuangan Perusahaan (Studi Pada Perusahaan Manufaktur Sektor Aneka Industri Tahun 2012-2016). Diponegoro Journal of Social And Politic Tahun 2018, Hal. 1-10. https://ejournal3.undip.ac.id/index.php /jiab/article/view/20329

Toto, P. (2011). Analisis Laporan Keuangan Teori Dan Aplikasi. Jakarta: Ppm.

Trianto, A. (2018). Analisis Laporan Keuangan Sebagai Alat Untuk Menilai Kinerja Keuangan Perusahaan Pada Pt. Bukit Asam (Persero) Tbk Tanjung Enim. Jurnal Ilmiah Ekonomi Global Masa Kini, 8(3), 110.

DOI: http://dx.doi.org/10.36982/jiegm k.v8i3.346

Warsono. (2012). Manajemen Keuangan Perusahaan. In Edisi Ketiga, Cetakanpertama,Bayumediapublishig, Jawatimur.

Wibowo, N. (2019). Pengaruh Firm Size Dan Leverage Ratio Terhadap Kinerja Keuangan Pada Perusahaan Pertambangan. Jurnal Wira Ekonomi Mikroskil: Jwem, 9(1), 13-20. https://mikroskil.ac.id/ejurnal/index.p 
hp/jwem/article/view/588

Yunita, A., Susyanti, J., \& Wahono, B. (2020). Pengaruh Analisis Current Ratio (Cr), Debt To Equity Ratio (Der) Dan Total Assets Turnover (Tato) Terhadap Penilaian Kinerja Keuangan Pada Ekonomi Kreatif Sub Sektor Fashion Di Kota Malang Tahun 2016-2018. Jurnal Ilmiah Riset Manajemen, $9(08)$. http://www.riset.unisma.ac.id/index.p $\mathrm{hp} / \mathrm{jrm} / \mathrm{article} / \mathrm{view} / 6245$

Zakiyah, E. N., Salim, M. A., \& Wahono, B. (2018). Pengaruh Struktur Modal Dan Ukuran Perusahaan Terhadap Kinerja Keuangan (Studi Kasus Pada Perusahaan Makanan Dan Minuman Yang Terdaftar Di Bursa Efek Indonesia Tahun 2014-2017). Jurnal Ilmiah Riset Manajemen, 7(9). http://riset.unisma.ac.id/index.php/jrm /article/view/1239/0 